\title{
Japanese forum urges rethink over patents
}

David Cyranoski, Tokyo

A group of leading experts in patents and technology transfer have called for a complete overhaul of Japan's intellectual-property system.

The National Forum for Intellectual Property Strategy, whose 11 members include business leaders, lawyers and academics, want reforms that will allow individual researchers to retain the rights to their inventions. The forum also says that Japan needs a patent office with greater technical capacity.

Hisamitsu Arai, a former head of the patent office and chairman of the forum, presented the 60-page reform plan to the Council for Science and Technology Policy (CSTP), the country's highest scientific policy-making group, on 15 January.

The plan's 100 proposals address intellectual-property issues in universities, industry and government. The group claims that its proposed changes could make Japan "the

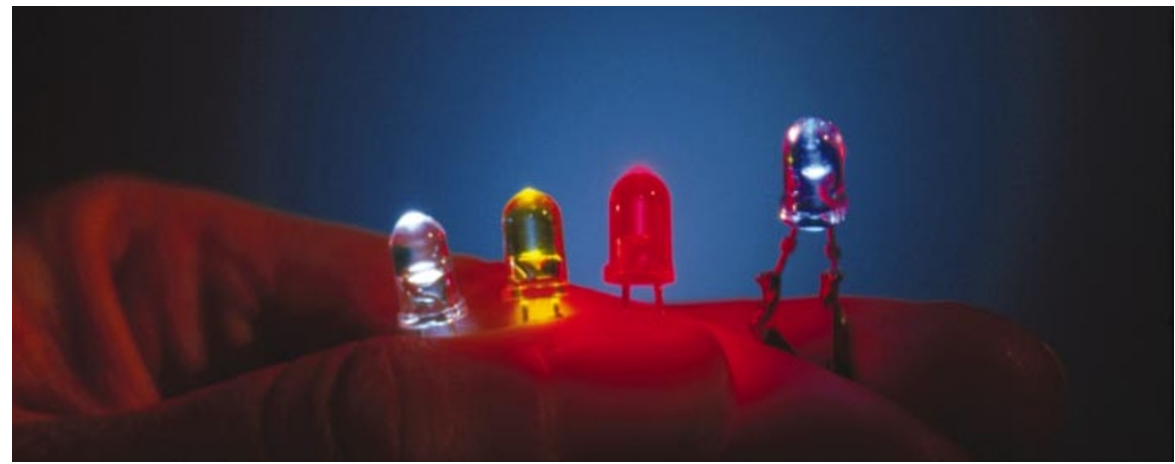

Light compensation: the blue LED's inventor Shuji Nakamura was less than satisfied with his reward.

world's number one intellectual-property country" by 2010 .

Supporters of the reforms cite an incident last year, in which two Japanese biologists were charged with industrial espionage in the United States after removing materials belonging to a former employer there, as

\section{Satellite set to keep track of whales}

\section{David Cyranoski, Tokyo}

A Japanese research team is putting the finishing touches to a satellite-based whaletracking system that looks set to fuel the international debate on whale conservation.

The system - the brainchild of Tomonao Hayashi, an engineer at the Chiba Institute of Technology - will use a satellite to probe the whereabouts of hundreds of whales.

Hayashi hopes the project will help to resolve the ongoing debate about Japan's whaling programme. Japanese researchers, mainly at the Institute for Cetacean Research (ICR) in Tokyo, say that whale stocks are sufficient to warrant hunting; the International Whaling Commission disagrees. To prove its point, Japan has been carrying out controversial 'research whaling', killing about 400 whales per year. "Both sides know too little about the whale's ecology to reach a conclusion," says Hayashi.

The project will initially involve just one or two whales until it proves its merit internationally, Hayashi says. The education ministry has invested $¥ 300$ million (US\$2.3 million) in the plan, and the satellite will be launched as part of Japan's Advanced Earth Observing Satellite II (ADEOS-II) project.

Researchers will tag the whales by using an airgun to shoot a titanium pin into the blubber, a procedure that Hayashi describes as "minimally invasive". A probe, attached to the pin by a two-metre rope, will send signals to the satellite.

Apart from allowing monitoring of migratory patterns and whale acoustics, the

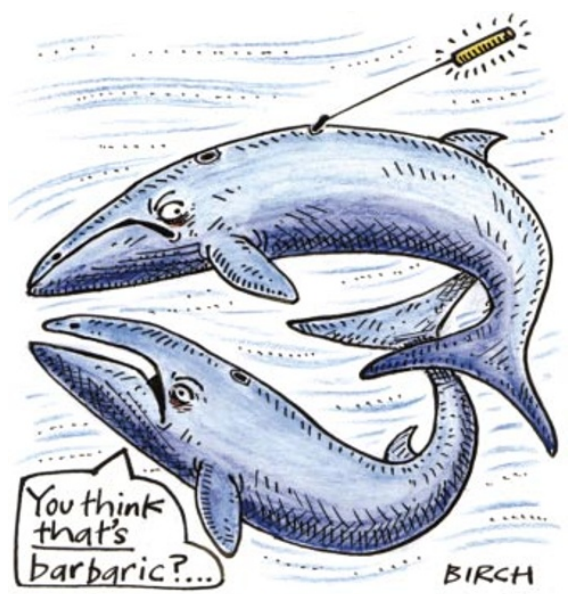

probes will record pressure and temperature, and take geomagnetic readings during whale dives, which can last for 10-30 minutes. Data will be relayed to the satellite whenever the whale surfaces. "Sperm whales are thought to dive 2,000-3,000 metres during this time, but no one could tell for sure," says Hayashi.

Hayashi is developing a special generator to recharge the probe's batteries - a propeller-like machine that will derive energy from the whale's motion through the water. Although the whales will probably be stuck with the pin for life, Hayashi plans to attach the rope and probe with an iron fastener that will eventually rust away.

Seiji Ohsumi, director-general of the ICR, says the research will be "epoch-making", adding that the project will help the institute to work on rational stock management. indicative of the low awareness of intellectualproperty rights issues in Japan. Lack of such knowledge led to the incident, they say.

Arai told the council that inventors, whether from a university or company, should be awarded patents as individuals, and that the accrual of patents should carry as much weight as the publication of research in the professional evaluation of researchers. The forum also calls for Japan to get tough on enforcing intellectual-property rights in other Asian countries, particularly China.

According to Arai, who is chairman of Nippon Export and Investment Insurance, patents in Japan "are just jewellery, a costly decoration. They're expensive but they earn little profit on average."

Corporations tend to give the same low level of reward for any patent taken out by researchers, says Arai. He notes the unfairness of this for big money-making products such as the blue-light-emitting diode discovered by Shuji Nakamura while at the Nichia Corporation. Nakamura, who advised the forum, cited low compensation as part of his reason for moving from the Japanese company to a university in the United States (see Nature 412, 844; 2001).

Lack of trained manpower also dogs the Japanese patent system, the forum says. "There are no PhD-holders in Japan's patent office, against some 500 in the US patent office," says Koichi Sumikura, an expert in intellectual-property rules in biology at the National Graduate Institute for Policy Studies in Tokyo.

"The CSTP agrees with most of these proposals," says Hiroo Imura, a member of the council. "But some, such as the idea that individuals rather than research organizations should own the intellectual property, remain contentious." And Arai accepts that some of the proposals will be unpopular with academic researchers.

Nonetheless, patent reform is on the cards in Japan before long. The CSTP meets again this week to discuss the best way forward. "Intellectual property is a big topic now," says Imura. 